\title{
AS ORIGENS DAS COMEMORAÇÕES DO NATAL $\left(^{\star}\right)$.
}

A festa de Natal (1) nem sempre foi celebrada a 25 de dezembro. $\mathrm{Na}$ falta de qualquer documento que registrasse o dia de nascimento de Jesus, os cristãos procuraram, a princípio, as hipóteses mais fantásticas e contraditórias. Mais tarde, já no século III, as Igrejas do Oriente passaram a comemorar a Natividade no dia da Epifania (5-6 de janeiro). Sòmente a partir do século IV, é que a Igreja de Roma encontrou outra data, o dia 25 de dezembro, que era a data em que se celfichrava a festa do Sol, e que lentamente veio a impor-se para tôda a Cristandade.

$\mathrm{Na}$ realidade, os primeiros cristãos não tiveram sequer em mente celebrar o aniversário do nascimento de Jesus. Para êles, importava mais o aniversário de sua morte, assim como o de sua ressurreição, isto é, o de sua vitória sôbre a morte. Por essa razão é que a Páscoa constituia, para êles, a grande data anual. Com êsse mesmo espírito a Igreja dos primeiros séculos celebrava seus mártires no aniversário de sua morte, e não no de seu nascimento; registrando os seus nomes, em seu calendário, ao lado do nome de Cristo (2).

O apologista cristão Arnóbio (VII, 32), por volta do ano 296, ridiculariza os pagãos que celebram o dia de nascimento

(*). - Artigo traduzido da Revue d'Histoire et de Philosophie religieuses (1931). Publicação da Faculdade de Teologia protestante da Universidade de Estrasburgo, págs. 256-274. Tradução de Lineu de Camargo Schützer (Nota da Redação).

(1). - L. Duchesne, Les origines du culte chrétien, 5a. edição. Paris. 1920; Hendrix, Congrès d'Histoire du Christianisme (1928); $R$. Herdt, La fête de NoëI, Paris (1927); A. Meyer, Das Weihnachfest, Tubingue (1913); G. Rietschel, Weihnachten, Leipzig (1902); P. Saintyves, L'arbre des Nymphes, Paris (1918) e Essais de Folklore biblique, Paris (1918); U. Usener, Das Weihnachtsfest, 2a. edição, Bonn (1911); P. Vallette, Le dieu Soleil et la fête de Noël (Bibliothèque universelle et Revue Suisse, janeiro de 1910).

(2). - Vacandard, Etude de critique ef d'histoire' rellgieuse (3a. série), p. 5. Paris. 
dos deuses, julgando que é indigno de um deus ter recebido o sôpro de vida a partir de um dia determinado. O próprio Clemente de Alexandria, lá pelo ano 200, se diverte daqueles que procuram não sòmente o ano mas ainda o dia do nascimento de Cristo. Pergunta que valor podem ter cálculos que levam, uns a marcar o dia 19 de abril, outros 30 de maio!

Um dos exemplos dêstes cálculos - e que leva a 28 de março, encontra-se no De Pascha compustus, escrito publicado em 243 e que se vê nos apêndices das edições de São Cipriano, sem ser, porém, de sua autoria. Inicialmente é assentado que o primeiro dia da criação em que "Deus separou das trevas a luz" deve coincidir com o equinóxio, momento em que o dia e a noite tinham igual duração; portanto, a 25 de março, segundo o calendário Juliano. $O$ Sol, criado no quarto dia, apareceu portanto a 28 de março. Na realidade a argumentação complica-se por um simbolismo ainda mais exagerado, aplicado aos números.

Segundo ${ }_{\text {S }}$ cálculos de Hipólito e seu ciclo pascal (222), gravado em sua estátua conservada na biblioteca de São João de Latrão, em Roma, a vida do Senhor teve início no ano do mundo 5.502 , a 2 de abril ou a 2 de janeiro, conforme se queira traduzir gênesis por "nascimento" ou por "concepção", e a sua morte teria ocorrido em 5.532 , isto é, trinta anos mais tarde. O ponto de partida dos cálculos de Hipólito é a coincidência da Páscoa cristã com o plenilúnio, e a comparação do ano lunar com o ano solar; infelizmente o ano lunar dêste autor tem nove horas a menos, o que falseia todos os seus cálculos. Uma pretensa correção de Hipólito; em seus comentários sôbre Daniel (235) é geralmente atribuída a uma interpolação. De acôrdo com esta correção, Cristo teria nascido a 5.500 , porque a arca da Aliança teria tido cinco côvados e meio (total de suas dimensões); Cristo teria morrido a 25 de março do ano 29 , teria sido concebido trinta e três anos antes e, portanto, teria nascido nove meses depois, a saber, a 25 de dezembro do ano 5.500 após Adão.

Neste, como em outros cálculos, só têm importância os números inteiros, pois as frações são imperfeições incompatíveis com a santidade do Salvador.

A Epifania. - Entretanto, êstes cálculos não tiveram qualquer importância na escolha da data da Natividade quando no século III - os cristãos vieram, primeiramente, a celebrála. Todo o Oriente cristão adotou, de comum acôrdo, a data de 5-6 de janeiro, dia da Epifania de Dionisos. Na verdade, a re- 
-cordação desta festa permanecera muito viva entre êsses cristãos recém-convertidos. Era uma crença já antiga que a epifania de um deus, isto é, sua aparição, confundia-se com o seu nascimento. Em Delfos, no comêço do mês bisios, a Epifania de Apolo era celebrada pela designação de teofania porque então, pela primeira vez, o deus se manifestara (3).

A 6 de janeiro e na noite que precedia, comemorava-se, pois, a Epifania de Dionisos. Este deus, originário da Trácia, era de grande prestígio em todo o mundo grego onde o seu culto, pouco a pouco, perdeu sua antiga forma bárbara. E' conhecida a lenda de Dionisos-Zagreus, desmembrado pelos Titãs e vingado por Zeus que os fulminou. Das cinzas dos Titãs nasceu o gênero humano. Os homens são, pois, impuros como aquêles dos quais procedem; mas nas cinzas dos Titãs havia também a substância do ser divino que êles haviam comido; e por essa razão permanece igualmente nos homens uma centelha divina. $E^{\prime}$ à libertação dêste elemento divino, pela posse definitiva da imortalidade bem-aventurada, que tendem os eleitos de Dionisos, pelo menos aqueles que são salvos pela graça que se consegue através da iniciação, da qual Orfeu instituiu o culto.. $O$ jovem deus da Trácia, que ressuscitou, aparece pois como um deus salvador. Contràriamente aos deuses de Homero, que concediam seus favores apenas aos grandes dêste mundo, Dionisos é o deus dos escravos e dos pobres tanto quanto dos ricos; interessa-se pelo destino de todos êles. Em conseqüência de sua origem, Dionisos é sempre o espírito da renovação anual da vegetação. Ele não se tornou o deus do vinho senão nas regiōes vinhateiras. Na qualidade de deus de uma estação do ano, êle morre com o declínio da vegetação para ressuscitar com o aumento da luz que fomenta a vida, isto é, com o solstício de inverno, fixado primitivamente a 5 de janeiro (4) .

No dia da Epifania acendiam-se fogos. Por ocasião de sua Epifania (noite de 5 para 6 de janeiro e dia 6 de janeiro), em algumas localidades o deus manifestava sua invisível presença pela aparição miraculosa de vinho, como narram Plínio-o-Velho (História Natural) e Pausanias; os eleanos, em particular, foram favorecidos por êste milagre, assim como a ilha de Andros, onde o vinho corria espontâneamente no templo durante a festa de Dionisos. Santo Epifâno (367-403), bispo de Salamis em Chipre, afirma (Haeres, II, 30) que, por um prodígio muito surpreendente, viam-se em seu tempo, em vários lugares, diver-

(3). - Hendrix, op. cit., t. II, pág. 219.

(4). - A. Meyer, op. cit., págs. 13 e segs. 
sas fontes e alguns rios cuja água se transmudava em vinho, ou lhe tomava o gôsto e a côr, no referido dia (6 de janeiro), aniversário do milagre realizado por Jesus Cristo. Afirma que êle próprio provou o vinho de uma dessas fontes, situada em Cibise na Asia Menor; declara mais que alguns monges, seus conhecidos, tiveram o mesmo privilégio ao provarem água de uma outra fonte que estava na cidade de Gerasa, na Arábia. Acrescenta que alguns assoalham que o Nilo, em certo ponto. de seu curso, é favorecido com o mesmo milagre, no dia da Epifania de Osiris, e que os egípcios aproveitam-se dêsse milagre para aprovisionar-se de vinho em suas casas (5).

A Liturgia havia fixado o milagre de Caná a 5-6 de janeiro, como lembra Epifano, e trinta e um anos após o nascimento. de Jesus, dia por dia. Assim Cristo tomara o lugar de Dionisos (6), o que deu ensejo a dizer-se que "desde o culto de Dionísos até o culto cristão, jamais cessou de se mudar água em vinho: cada 6 de janeiro".

Esta crença subsistiu até nossos dias; e no Tirol, na Suábia, em Flandres, o povo ainda acredita que na época de Natal, a água se transforma em vinho. $\mathrm{Na}$ Baixa Bretanha supõe-se que as fontes jorram vinho durante a missa de Natal e, mais exatamente, no momento da consagração. Em Guernessei, imagina-se que o mesmo ocorreria naquele dia, à meia-noite (7).

Epifano narra, em sua história das heresias, que em Alexandria, durante a noite de 5 para 6 de janeiro, celebrava-se uma grande festa em honra do Aeon, ser eterno, filho de Koré. A comunidade reunia-se à noite no templo de Koré, que era honrada por meio de cânticos e música de flautas. Koré não era outra senão Perséfone, a deusa subterrânea. Após o cantar do galo, tiravam da sua cripta uma imagem de madeira esculpida, que representava a deusa sentada, assinalada com cinco cruzes douradas, uma sôbre a fronte, uma sôbre cada mão e uma sôbre cada joelho. Levavam a estátua em tôrno do templo sete vêzes em seguida, antes de reconduzi-la ao sūbterrâneo. Cânticos litúrgicos que acompanhavam esta procissão celebravam a Epifania do Aeon, ao som das flautas e címbalos: "Nessa hora, proclamava-se, Koré - que é a Virgem, gerou o Aeon (a mesma divindade Osiris e Dionisos)". No mesmo dia (6 de janeiro), sempre em Alexandria, celebravam também uma festa em honra de Osiris. Tiravam solenemente água do Nilo. A recor-

(5). - P. Saintyves, Essais..., pág. 219.

(6). - Idem, Revue..., pág. 107.

(7). - A. Meyer, op. cit., pág. 17 e Saintyves, Essais..., pág. 219. 
dação dessa festa de água se encontra nos ritos da Igreja grega: na véspera da Epifania e na manhã do dia 6, o bispo benze a fonte no átrio da Igreja, repetindo orações litúrgicas muito antigas (8) .

Este acúmulo de comemorações que coincidiam no dia da Epifania é, em parte, recordado no trecho tria miracula da antífona de Vésperas do Breviário romano, antífona que evidentemente é de origem grega: " $E$ ' neste dia que a estrêla conduziu os magos à manjedoura, neste dia que a água se transformou em vinho nas bodas (de Caná), é neste dia que Cristo quis ser batizado por João no Jordão para nossa salvação".

O dia da Epifania é, ainda, o aniversário da multiplicação dos pães.

E' também em Alexandria, no século II, que encontramos pela primeira vez a Epifania celebrada num ambiente cristão não ortodoxo, mas herético: "Os adeptos de Basílides, conta-nos Clemente de Alexandria (220) em seu primeiro livro do Stromatas, celebram o dia do batismo de Jesus passando a noite, antes da festa, em leituras. E afirmam que êle ocorreu no décimo quinto ano do imperador Tibério, no quinto dia do mês (egípcio) de tubi (é a 6 de janeiro), mas alguns afirmam que foi a 11 do mesmo mês (12 de janeiro). Basilides exerceu sua autoridade em Alexandria ao tempo do imperador Adriano. Seu docetismo moderado o distanciava menos do Cristianismo ortodoxo do que as outras seitas gnósticas (9) .

Os gnósticos consideravam o dia do batismo de Jesus como sendo o da sua epifania, porque foi sòmente nesse dia que êle recebeu o Espírito divino em forma de uma pomba, com as palavras da consagração: "Tu és meu Filho dileto, em ti me agrado". Foi nesse dia que Jesus se tornou o Cristo ou o primogênito dos eleitos.

Para os gnósticos, Cristo era o mensageiro dos divinos segredos, trazidos por êle à terra. Os gnósticos procuravam alcançar o conhecimento dêsses segredos, isto é, a. "gnose verdadeira" que os devia conduzir à união com Deus, à posse das fôrças divinas, à salvação (10) .

Após Basílides e talvez seguindo o exemplo de sua seita, a Igreja comemorou a Epifania como sendo o aniversário do batismo de Jesus e de seu nascimento; acontecimentos que teriam ocorrido, dia por dia, a trinta anos de intervalo; considerados

\footnotetext{
(8). - Usener, op. cit., págs. 27 e 28; Hendrix, op. cit., págs. 220-222 e pág. 227.

(9). - Hendrix, op. cit., págs. 222, 223 e 225.

(10). - A. Meyer, op. cit., pág. 7 e segs.
} 
apenas os números inteiros que eram os únicos condizentes com a perfeição do Cristo, como acima dissemos. No início do século III, a festa da Epifania não perece merecer grande consideração entre os ortodoxos, mesmo em Alexandria, pois Orígenes não a menciona na lista das festividades cristãs que êle refere em seu Contra Celsum. Entretanto, a Epifania cristã se teria impôsto bem depressa no Oriente, segundo o Testamento de Jesus Cristo, onde ela é duas vêzes mencionada como uma das maiores festas do ano, se é verdade que esta obra data da primeira metade do século III, como sustentam alguns críticos (11). O que é certo que a Epifania cristã era celebrada naTrácia por volta do ano 300; sendo já mencionada na Paixão de São Filipe, bispo de Heracles (304). Na mesma época, na Ásia Menor, ela é celebrada por São Gregório de Neo-Cesaréia e também comemorada no Egito (papiro de Faium). Um poııco mais tarde, em 361, a festa é confirmada na Gália por Amiano Marcelino (XXI, 2), o qual relata que Juliano assistiu pùblicamente ao ofício cristão em Viena, no dia da Epifania. O concílio de Saragossa, de 380 , a declara uma das maiores festas do ano. $\mathrm{Na}$ Africa veio ela a ser adotada por tôda parte; e pode-se afirmar que, pelo ano de 380, a festa da Epifania está espalhada em todo o Oriente.

Possuimos um relato que revela o brilho das festas da Epifania celebradas no Oriente, no século IV, em honra do nascimento de Cristo. Devemos esta narração à peregrina espanhola Etéria que passou três anos na Palestina, por volta do ano 380 . Ela se extasia com o brilhantismo da festividade, celebrada a 6 de janeiro e nos dias seguintes, nas basílicas de Belém, da Cruz e da Anastasia. Mostra-se ainda muito impresisonada pela luz dos círios, dos candelabros e das lâmpadas, bem como pelo brilho do ouro, das gemas, do mármore e das tapeçarias de sêda. A beleza dos cânticos no meio de uma considerável multidão tocaram-na vivamente. "Durante oito dias; diz ela, todos os lugares santos presenciam a alegria geral e pomposas cerimônias".

A epirania cristã, como a pagã, celebrava-se com luminárias de tochas. Era a festa das candelárias, como diz Gregório de Nazianza (Orat. 39), porque celebra o dia que iluminou a humanidade. " $E$ ' hoje - declara o bispo da Igreja grega, ao repetir o poema do patriarca de Sofrônios - que se levantou o sol para não mais se deitar, e o universo está iluminado pela

(11). - As críticas não se extendem infelizmente sôbre a data dessa obra. Alguns autores a fazem remontar ao IV século ou mesmo mais tarde. 
luz do Senhor". - "E' hoje, canta a Igreja grega no seu Horológio, que te manifestaste ao mundo e que tua luz, ó Senhor, revelou-se a nós; e, ao pleno conhecimento disto, aclamamos-te cantando: Tu vieste, tu te mostraste, tu, a luz inacessível" (12).

O natal de 25 de dezembro. - A Igreja romana começou também por celebrar o nascimento ao mesmo tempo que o batismo de Jesus no dia da Epifania; e sòmente no século IV é que ela transferiu a Natividade para 25 de dezembro (13). Seu exemplo foi seguido pelo Oriente. $\mathrm{Na}$ escolha de 25 de dezembro houve uma vez mais a substituição de uma festa pagã por uma festa cristã. A festividade pagã era a festa do Sol. A êste astro se prestava um culto importante no Império Romano, pouco após o início da éra cristã. Por influência da astrologia oriental, que associa o destino dos indivíduos ao curso dos astros, julgava-se que o Sol presidia o destino dos reis; é êle que os eleva ao trono ou os faz descer, é êle que os conduz ao triunfo ou consente sua derrota. Nesta corrente de idéias, o imperador romano veio a ser considerado, em breve tempo, como sendo a emanação do Sol. Aureliano mandou erigir urn templo ao Sol invictus, isto é, ao deus solar que, cada manhã, triunfa da noite, e que lhe dera a vitória na Síria.

Em Roma, o culto do Sol foi fortalecido com a introdução, no Ocidente, do culto de Mitra, originário do Irã, nas margens do Eufrates. E' a antiga religião mazdeista dos ancestrais dos persas. Mitra, o gênio da luz celeste, foi assimilado ao Sol por influência dos caldeus. Foi introduzido na Itália pelos escravos e pelos soldados, e a religião de Mitra se estabeleceu no próprio coração de Roma desde o ano 181 a. C. alcançando proteçâo imperial: Cômodo tornou-se um "iniciado" nos mistérios mítricos; Diocleciano, Galério e Licínio ostentaram sua devoção a Mitra construindo-lhe um templo em Carnuntum, em 307, e Juliano-o-Apóstata foi um ardoroso adepto de Mitra, que êle ordenou fôsse adorado em seu palácio de Constantinopla.

O templo de Aureliano foi inaugurado a 25 de dezembro de 274. Era também a 25 de dezembro que a Roma pagã celebrava o nascimento anual do Sol porque, segundo o calendá-

\footnotetext{
(12). - Passagens citadas por Hendrix, op. cit., pág. 227.

13). -gundo Duchesne, ao contrário (Origines du culte chrétien, pág. 271), o Natal e o Batismo foram celebrados simultâneamente em 6 de janeiro no Oriente e países ocidentais de rito galicano (Alta-Itália, Gália, Espanha), mas Roma não teria jamais aceitado a Epifania a não ser como aniversário do batismo de Cristo e sòmente após ter a Igreja romana determinado (IV século) que em 25 de dezembro fôsse celebrado o Natal.
} 
rio Juliano, a data de 25 de dezembro era considerada como o solstício de inverno, e, portanto, como o momento do ano a partir do qual os dias começam a alongar-se e o Sol a brilhar com mais fulgor. Era uma das grandes festas do paganismo; solenes. e magníficos jogos eram promovidos pelo soberano em honra. do Sol Invencível.

As costumeiras vinte e cinco corriajas do circo eram elevadas a trinta para lembrar o número mensal do curso do Sol em tôrno da terra. A multidão se aglomerava nessas comemorações; os próprios cristãos participavam dêsses divertimentos sem. poderem permanecer isentos do contágio de uma alegria geral . O Papa São Leão conta-nos mesmo que os fiéis, após assistirem aos ofícios divinos na basílica de São Pedro, se reuniam ao mesmo dia com os místicos de Mitra para tomarem parte na liturgia do mistério mítrico. Acreditava-se, ao que parece, que as grandes fogueiras acesas para festejar o incremento da luz auxiliavam o Sol a subir acima do horizonte. Esta concomitância mágica - conquanto tenha perdido hoje em dia seu significado - subsistiu até em nossas festas de Natal, em que são. acendidas velas na árvore. Ainda atualmente, por ocasião de um eclipse do sol, os índios ojebways projetam no ar flechas incenciadas para lembrar ao sol seu dever; enquanto que no Kamtchatka os indígenas acendem fogueiras junto a suas cabanas e pedem ao sol para brilhar novamente.

A falta de documentos, que registrassem a data do nascimento de Cristo, deixou a Igreja romana completamente livrepara fazer coincidir aquêle aniversário com o solstício de inverno do calendário romano, isto é, com o dia 25 de dezembro. $\mathrm{E}$ assim fazendo, a Igreja de bom grado opunha, a Mitra, Aquêle a quem ela adorava como "o Sol da justiça" predito por Malaquias (IV, 2). Acaso o velho Simeão não havia também saudado o menino Jesus como "luz para iluminar os gentios"? A primitiva literatura cristã usa a mesma expressão: São Cipriano $(\uparrow 258)$ designa Cristo como o "verdadeiro Sol". "Esste é o nosso nôvo sol", proclama Santo Ambrósio († 397). Expressões: semelhantes a estas encontram-se freqüentemente em Gregório de Nazianza $(\uparrow 389)$, São João Crisóstomo ( $†$ 407), Zenon de Verona, e muitos outros Santos Padres. E são elas encontradas, também, em todo o ofício do Natal (14).

Um escritor sírio e cristão, escoliasta de Bar-Salibi, diz claramente: "Esta é a razão pela qual os Santos Padres transfe-

(14). - Vacandard, op. cit., págs. 16 e 17. 
riram para 25 de dezembro a festa de 6 de janeiro. Era costume entre os pagãos celebrar-se nessa data de 25 de dezembro o aniversário do Sol e acender então fogueiras em honra dessa festividade. Os pagãos permitiam aos cristãos tomarem parte nessas alegrias e solenidades. Assim, quando os doutores da Igreja perceberam que os cristãos se alegravam em participar daquelas festividades, resolveram celebrar nesse dia a verdadeira Natividade e deixaram a Epifania para o dia 6 de janeiro. Eis porque esta prática foi conservada até nossa época, com o costume de acender fogueiras" (15) .

$\mathrm{E}$, mais tarde, as fogueiras do solstício, acendidas pelos romanos, vieram a arder também na Síria.

Santo Agostinho alude à origem pagã do Natal quando exorta seus irmãos cristãos a não celebrar, nesse dia solene, o sol, como os pagãos, mas Aquêle que criou o sol. Igualmente Leão-o-Grande deplora a crença censurável que consistia em celebrar o Natal por causa do nascimento do nôvo Sol, como o chamavam, e não por causa do nascimento de Cristo.

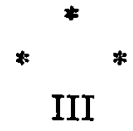

Os adeptos de Mitra, muito numerosos no Império Romano e no Oriente, não eram os únicos a festejar o solstício de inverno. Também na Síria e no Egito, os fiéis se retiravam para certos santuários secretos, de onde saíam à meia-noite, exclamando: "A virgem deu à luz! A luminosidade aumenta!" Os egípcios chegavam mesmo a representar o "Sol recém-nascido", figurado pela imagem de uma criancinha que mostravam a seus adoradores, no dia do seu nascimento, no solstício de inverno. A virgem "que dava à luz uma criança a 25 de dezembro era sem dúvida a grande deusa oriental que os semitas denominavam a Virgem celeste, ou simplesmente, a Deusa celeste; ela era, nos países semitas, uma forma de Astarté. Chamavam-na a Rainha do Céu (Jeremias VII, 18; XLIV, 13), a Deusa celeste (Heródoto III, 8; Pausânias I, 14,7) ou a Virgem celeste (Tertuliano, Apologeticus, 23; Santo Agostinho, De Civitate Dei, II, 4). Os gregos a mencionavam como a divina Afrodite (Heródoto I, 105; Pausânias, I, 14, 7)" (16).

(15). - Usener, op. cit., págs. 349 e segs.

(16). - Citado por Frazer, Atys et Osiris, págs. 29 e 30 , apud F. Cumont, s. v. Caelestis in Real-Encyclopédie der classischen Altertumwissenschaft de Pauly-Wissowa, V, I, e s 1274 e segs. 
Encontramos o nascimento de Cristo mencionado pela primeira vez em Roma a 25 de dezembro, no calendário Filocaliano de 354. Furio Filocalo é o nome do calígrafo e iluminador que se supõe ter editado êste calendário. Segundo êste calendário, no ano 336 estava consagrado, em Roma, o uso de se considerar o dia 25 de dezembro como o aniversário do nascimento de Jesus (17). Mas sòmente em 353, sendo Papa Libério, é que foi instituída, em Roma, a festa do Natal.

Quanto à Epifania, aniversário do batismo de Jesus, não é ela mencionada no calendário filocaliano de 354; do que se conclui que não era celebrada em Roma, até a êsse tempo. Poróm, era seguramente celebrada no ano 400, pois Arcádio e Honório proibiram, nesse dia, os jogos do circo. Um pouco mais tarde, Justiniano suspende as sessões judiciais no referido dia, como nos dias feriados.

Assim, desde o início do século $\mathrm{V}$, as festividades do Natal e da Epifania haviam já sido adotadas em todo o Ocidente, exceto entre os donatistas.

De Roma, a festa cristã de 25 de dezembro se irradiou e veio a espalhar-se a tôda a Cristandade. Porém, ela não conseguiu impor-se com a mesma facilidade por tôda parte. No Oriente, encontrou Igrejas que se apegavam firmemente a 6 de janeiro como sendo o dia da Natividade. A resistência foi particularmente forte na Síria, de modo especial em Antioquia onde, havia dez anos, aproximadamente, Roma tentava inùtilmente fazer adotar pela liturgia a festividade de 25 de dezembro, quando finalmente São João Crisóstomo, por ocasião deum sermão pronunciado a 20 de dezembro de 386 ou 387 , em memória de Santo Filógono, mártir de Antioquia, insistiu com seus ouvintes para que viessem em grande número, cinco dias depois, a fim de festejarem a Natividade em tôrno da manjedoura. Uma considerável afluência respondeu ao seu convite a 25 de dezembro. Êle tentou então convencê-los da coincidência desta data com o aniversário do nascimento de Cristo: "Os

(17). - Mommsen, Abhandl. der saechs. Académie der Wissensch. (1850), t. 618 . - No Depositio martyrum dêsse documento, 1ê-se: VII. Kal (I) mense Januario natus Christus in Bethleem Judae; isto é, o oitavo dia das calendas de janeíro (25 de dezembro): nascimento de Cristo em Belém da Judéla.

I p. chr. Caesare er Paulo sat. XIII. Hoc cons. Dns. chs. XPC natur est VWI Kal. Jan. de ven. Iuna $x v$, o que significa: Jesus Cristo nasceu durante o consulado de César Augusto e de L. Aemilius Paulus (754) em 25 de dezembro, que era uma sexta-feira, o quinto dia da nova lua. 0 número XIII indica a Epacta, a palavra Sat. quer dizer Saturni e desempenha o papel de letra dominical. Isso indica que o $10^{\circ}$ de janeiro caia num sábado; logo $B$ era a letra dominical. 
romanos, que celebram o nascimento do Salvador a 25 de dezembro - declarou, assim o fazem com conhecimento de causa, êles que possuem o registro do recenseamento ordenado por Augusto e, portanto, a data da vinda de José e Maria a Belém". Para vencer as últimas hesitações de seus ouvintes, o. orador lhes lembrou que, segundo Lucas, Isabel concebeu João. Batista no dia em que seu marido, o sumo-sacerdote Zacarias, saiu do Santo dos Santos. Esse recinto sagrado só recebia a visita do sumo-sacerdote uma vez por ano. Apoiando-se em numerosos textos do Levítico, São João Crisóstomo demonstra que não podia tratar-se senão do dia da festa dos Tabernáculos, isto é, a 24 de setembro. Ora, a anunciação ocorreu seis meses depois (Lucas I, 26 e 56), isto é, a 25 de março, e o nascimento. de Jesus nove meses mais tarde, isto é, a 25 de dezembro. Esta demonstração era tão fantasiosa como a primeira, mesmo se supusermos que Zacarias era sumo-sacerdote, o que não é exato; além disso, era uma demonstração a posteriori, isto é, tendente a justificar uma situação de fato. Entretanto parece que os ouvintes ficaram convencidos, como o testificam o calendário da Igreja de Antioquia e das demais Igrejas da Síria, em. que as festividades da Natividade e da Epifania figuram respectivamente a 25 de dezembro e a 6 de janeiro.

Uma argumentação do mesmo tipo era corrente naquela época para sustentar as reivindicações de Roma: a data em que Maria concebeu não poderia sèr outra senão 25 de março, aniversário da Criação, em razão de símbolos a que se apegavam os primeiros cristãos; portanto o nascimento de Cristo, ocorrido nove meses depois, deu-se a 25 de dezembro. Além disto, João Batista nasceu seguramente a 25 de junho, o dia. mais longo do ano, segundo o calendário Juliano, uma vez que o próprio Batista declarou: " $E$ ' preciso que êle cresça e que eu diminua". O Senhor, nascido seis meses depois (segundo. Lucas I, 26, 56), foi dado à luz, portanto, a 25 de dezembro.

A festa de Natal, celebrada na Capadócia, veio a ser, após alguns anos, introduzida em Constantinopla, em 379, por Gregório de Nazianza. Porém, após a sua saída, ela desapareceu de Constantinopla em 381, sòmente sendo restabelecida por volta do ano de 400, por São João Crisóstomo, que era o bispo de então. Durante os últimos anos do século IV, a festa de Natal, em 25 de dezembro, se espalhou ràpidamente por todo 0 . Oriente. 
O Egito foi mais rebelde e não se deixou convencer senão entre os anos 418 e 432 . Sabemos que, já em tôrno a 430 , em Alexandria se celebra a Epifania a 6 de janeiro e a Natividade a 25 de dezembro. A 25 de dezembro de 432, Paulo de Emesá profere um discurso sôbre a Natividade em presença de Cirilo de Alexandria, a quem viera visitar. E desde 432, a festa da Natividade se conservou no Egito, como provam seus' calendários.

Em Jerusalém, no comêço do século $V$, ainda não se conhecia a festividade de 25 de dezembro. Ao pretender introduzir em seu ministério de Belém o uso romano, São Jerônimo encontrou oposição tenaz. " $E$ ' certamente neste dia que nasceu Cristo, afirmava êle. Alguns pensam ter êle nascido na Epifania... O universo inteiro protesta contra esta opinião. Alguém dirá talvez: foi aqui o lugar do nascimento de Cristo; estrangeiros estariam acaso melhor informados que aquêles que vivem na própria localidade? Mas donde provêm vossas informações? Será daqueles que estavam nesta província, dos apóstolos Pedro e Paulo, bem como dos outros apóstolos? Vós os exilastes, nós os acolhemos. Pedro, que aqui esteve com João, que aqui esteve com Tiago, nos introduziu no Ocidente; assim, pois, os apóstolos são tanto nossos mestres como vossos". Em seguida, Sã̃o Jerônimo passa a outro argumento: "Os habitantes de Jerusalém, tão orgulhosos de serem os depositários da primitiva tradição, esquecem que sua cidade foi totalmente destruída e que, em certa época, sua localidade não continha mais nem judeus nem cristãos. Por que lembrar tudo isso? pensareis. Porque me dizeis: ' $E$ ' aqui que estiveram os apóstolos; aqui é que se encontra a tradição!" Vossa tradição não existe. Quanto a nós, afirmamos que Cristo nasceu neste dia; a Epifania é o dia de seu batismo" (18). Suas demonstrações não convenceram, e a Igreja de Jerusalém continuou a celebrar a Natividade a 6 de janeiro, pelo menos até o século VI, sẹgundo parece.

De seu lado, as Igrejas da Armênia e da Mesopotâmia só adotaram nossa festa de Natal a partir do século XIV. Atualmente, os monofisitas armênios não conhecem a festividade de 25 de dezembro e ainda celebram a Natividade a 6 de jareiro.

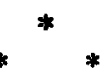

(18). - Sermão citado por dom Morin in Revue d'histoire et littérature religieuse, t. I (1896), págs. 415 e 416, citado por Vacandară, op. cit., págs. 26-28. 
A manjedoura e a gruta. - A tradição da manjedoura e da gruta remonta, pelo menos, ao século II. Segundo Orígenes e Santo Epifano, remontaria ela aos próprios Evangelhos. conquanto nos Evangelhos canônicos não se encontre qualquer alusão à gruta. Diz Orígenes, em 248: "Acêrca do nascimento de Jesus em Belém, se alguém quisesse outras provas, após as profecias de Miquéias, após a história relatada nos Evangelhos pelos discípulos de Jesus, saiba que, de acôrdo com o que está narrado nos Evangelhos sôbre o seu nascimento, mostra-se em Belém a gruta na qual nasceu, nesta gruta a manjedoura onde êle esteve enfaixado. $\mathrm{E}$ o que desta maneira se mostra é muito conhecido nestes lugares, melhor por aquêles que são estranhos à nossa fé, a saber, que o Jesus adorado e admirado pelos cristãos nasceu nesta gruta". Epifano não é menos categórico: "Lucas diz que, depois de nascido, o menino foi enfaixado e colocado numa manjedoura e numa gruta, porque não havia lugar no caravançará". "Como José não tinha onde se hospedar na aldeia, escreve ainda Justino, acomodou-se numa gruta bem próximo de Belém, e foi enquanto lá estavam que Maria deu à luz o Cristo e colocou-o numa manjedoura" (19). A menção da caverna se encontra também nos Evangelhos apócrifos (História de José, o carpinteiro, Evangelho da Infância, Proto-evangelho de Tiago, o Menor, Os Mistérios da Infância).

Nas igrejas católicas, na noite da Natividade, o povo vem orar em tôrno de uma manjedoura colocada numa gruta, que é geralmente representada por rochedos de papelão. Junto à manjedoura estão o asno e o boi da tradição. Estes animais estã̃o aqui presentes devido à interpretação fantasista dada por Orígenes a Isaías I, 3 :"O boi conhece o seu possuidor e o asno a manjedoura do seu dono". E' no decorrer do século IV que esta tradição aparece na arte cristã, de Rossi, e no século V que a ela se alude nos sermões de São Pedro Crisólogo. Em Weihnachten, de G. Rietschel (págs. 2-3, 1902). vêem-se reproduções de um afresco do século IV encontrado num túmulo de São Sebastião e também de um baixo-relêvo esculpido num sarcófago datado de 343; havendo, em ambos, o asno e o boi . A importância desta tradição é tal que desde então se encontram monumentos representando a manjedoura sem Maria e

(19). - P. Saintyves, L'arbre des nymphes, págs. 183 e 184. 
sem José, porém nunca sem o asno e sem o boi (Patrizi) (20). No próprio afresco e no baixo-relêvo que mencionamos, o menino Jesus figura com o asno e o boi, mas sem seus pais. Estes animais não tardaram em se constituirem símbolos, o boi representando os judeus, sujeitos ao jugo da Lei, e o asno os pagãos.

Provàvelmente, é porque os deuses solares usualmente nasciam em cavernas que se acreditou ter também Cristo - desde. logo assimilado a um Deus solar - nascido em uma gruta.

Os cretenses pretendiam que Zeus nasceu numa caverna do monte Ida, no centro de sua ilha. Dionisos nasceu numa caverna e Diodoro descreve a gruta arredondada em que foi criado. Agni nasceu também numa gruta, entre as vacas e os pastores; a êle, assim alude o Rig-Veda: "O recém-nascido tomou lugar no interior da manjedoura; mugiu o novilho junto à vaca. Os pastores vieram aclamá-lo, rodeando o lugar do nascimento do deus da verdade" (21).

Jerônimo diz que havia em Belém um bosque sagrado em honra de Adonis - o espírito do trigo - e que o luto de Adonis era celebrado na caverna onde vagiu o Cristo infante.

A adoração dos pastores não é, porém, um fato isolado. na tradição pagã. Nós a encontramos também na mitologia de Mitra, tendo ainda como cenário a gruta. "Textos precísos, escreve Cumont, informam-nos que, de acôrdo com a doutrina estabelecida nos mistérios, Mitra nascera de uma pedra... Nos baixos-relêvos da Transilvânia, o pastor ou pastores, pois às vêzes são em número de dois, contentam-se de observar, escondidos atrás de um rochedo, o nascimento miraculoso do divino menino, enquanto o rebanho pasta ou descança detrás dêles. A legenda de Mitra continha; pois, uma adoração dos pastores, análoga àquela narrada pelo Evangelho (Lucas' $\mathrm{II}$, 8)" (22) .

A árvore de Natal. - No pinheiro que conserva seu verdor e sua fôrça no inverno, e que após o mau tempo do inverno volta a cobrir-se de novos brotos, há o símbolo, desde muito tempo, de uma prodigiosa vida que êle pode comunicar ao seu redor em forma de uma longa existência e de uma saúde robusta. Isto tem sido ressaltado também com rela-

(20). - Vacandard, op. cit., pág. 46.

(21). - Ibidem, págs. 55, 84 e 139.

(22). - Cumont, Textes et monuments figurés, I, págs...159 e. 162. 
çã́o a outras árvores, sempre verdes, como o zimbro, o pinho, o azevinho, o agárico. Quanto mais ramos tem a árvore, maior é o seu poder em comunicar bênção. Eis porque, tradicionalmente, pelo menos nos países germânicos, colocam-se árvores verdes nas casas, no comêço do inverno; plantando-se também um pinheiro diante da casa ou junto à fonte, para trazer bênçãos ao lar e manter potável a água da fonte. Ainda atualmente consagra-se o término de uma casa colocando-se um ramo de pinheiro na cumieira (23). Estas árvores verdejantes são freqüentemente enfeitadas com fitas e ouropéis. As guloseimas e presentes colocados ao pé da árvore no comêço do ano, ali estão para assegurar abundância de pão e de riquezas durante o ano vindouro. Os animais de biscoito (cavalo, ganso, javali, êste substituído ulteriormente pelo porco) e as frutas que se penduram nas árvores de Natal, na Alemanha, são resquícios dè cerimônias pagãs nas quais se recordava a fecundidade da terra, e ao mesmo tempo se procurava provocar a sua continuidade. Era também um ato de gratidão para com os deuses generosos (24).

E' em Estrasburgo que, pela primeira vez, se menciona a árvore de Natal; a princípio na forma de ramo de pinheiro, mascote para o ano nôvo, no Narrenschiff (VI, 35 e segs.; ano 1424) de Sebastião Brandt:

"Aquêle que não canta, na ocasião do ano nôvo, $\mathrm{E}$ que não tem, em sua casa, o verde ramo do pinheiro, Poderá, com o seu povo, não ver o ano inteiro".

Não conhecemos a origem da nossa árvore de Natal. A menção mais antiga que dela temos data de 1605. Segundo ela, em Estrasburgo, no dia de Natal, erguia-se um pinheiro nas casas, no qual se colocavam rosas de papel colorido, maçãs, apitos e bombons, etc.... (25).

As luzes que ornamentam o pinheiro de Natal são mencionadas, pela primeira vez em 1785 , pela baronesa de Oberkirch, sempre com relação à árvore de Natal de Estrasburgo (26).

Partindo da Alsácia, o costume do pinheiro de Natal se divulgou através da Alemanha protestante. Em 1803, Hebel se refere a êle como um velho hábito entre os alemães da margem direita do Reno: "Dorme a criança, enquanto a mãe lhe pre-

(23). $\therefore$ A. Meyer, op cit., págs: 75-79.

(24). - Revue des traditions populaires, H. Heinecke, pág. 626 (1896).

(25). - A. Meyer, op. cit., pág. 119.

(26). - Thidem, pág. 120. 
para a árvore que ainda não está iluminada e que ainda está pendente do teto, no mesmo lugar em que os ancestrais penduravam seus ramos de bênção". De Estrasburgo a árvore de $\mathrm{Na}$ tal se transporta também para a Suíça, em Zurique, onde é mencionada em 1799 (27).

A árvore de Natal foi introduzida em Paris em 1840, no palácio das Tulherias, pela princesa de Mecklemburgo, duqueza de Orleans. A imperatriz Eugênia era muito inclinada às árvores de Natal. Em 1860, em Paris, na igreja luterana de Billettes, ofereceram uma árvore de Natal às crianças pobres de uma escola alemã. Foi também em 1840 que a árvore de Natal foi introduzida na côrte inglêsa por Alberto de Saxe-Coburgo, espôso da rainha Vitória (28).

O uso do pinheiro ou de outras árvores verdes, como portadores de bênçãos das casas ao início do inverno, foi diversas vêzes reprovado pela Igreja, que nêle via uma sobrevivência mágica do paganismo. Burchard, bispo de Worms (1000 a 1025) invoca um decreto do século III, do papa Marcial - que, na realidade, não era senão bispo de Limoges, proibindo ornamentar a casa, a $1 .^{\circ}$ de janeiro, com loureiro e ramos verdes (29). Em 1642, o pastor J. C. Dannhauer, de Estrasburgo, condena perante seus catecúmenos a árvore de Natal, seus enfeites e futilidades, como afastando-os de Cristo (30).

AUGUSTE HOLLARD

\footnotetext{
(27). - Tbidem, págs. 120-122

(28). - G. Rietschel, op. cit., pág: 154:

(29). - O bispo Martinho de Braga $(f$ 580) pronunciou a mesma interdição no seu capítulo. Tratava-se provàvelmente da mesma proibição A. Meyer, op. cit., pág. 77 e nota 50 ).

(30). - G. Rietschel, op. cit., pág. 145.
} 